\title{
A Drug Consumption Room in the Spanish Basque country
}

A professional interest in substance misuse coupled with a love of the people, culture, and language of Spain led me to investigate Bilbao's Sala de Consumo Supervisado or Drug Consumption Room (DCR) last February.

Bilbao, capital of the Spanish Basque Country (País Vasco) is Spain's largest port. It flanks the green and winding Rio Nirvión, a back drop of hills on both sides completes the scene. The streets are clean, sunny, and welcoming. The small 16th century shops and bars of the old town (Casco Viejo) buzz with tourist activity. Bilbao, like many European cities has undergone much regeneration in recent years. The spectacular and surreal Guggenheim Museum is its most famous achievement. 'El Gugg', as its known to the locals, is a pleasant half hour riverside walk from our hotel in Casco Viejo.

In common with many thriving European cities, Bilbao has a darker side. The revitalisation strategies tended to focus mainly on the physical regeneration of the city, while ignoring socioeconomic aspects. ${ }^{1}$ Social exclusion persists; directly below our walk the riverside arches provide shelter for the city's homeless. Although País Vasco is the most prosperous of Spain's autonomous regions, the more disadvantaged neighbourhoods of Bilbao have unemployment levels at around $14 \%$. This is inevitably linked with the related social issues of poor educational achievement, street crime, prostitution, poor health, and drug misuse.

Against this background, the Basque government commissioned Médicos Del Mundo to provide the DCR, which opened in 2003. ${ }^{2}$ DCRs are defined as 'protected places for hygienic consumption of preobtained drugs in a non-judgmental environment under the supervision of trained staff'. ${ }^{3}$ They have links with the wider network of drug services and have been shown to enhance the uptake of medical care and reduce overdose related deaths. They are likely to curb the transmission of blood borne viruses. DCRs reduce homelessness and social exclusion, while having no effect on local crime levels or individual drug consumption. ${ }^{4}$

The Netherlands, Germany, Switzerland, Canada, and Australia all have DCRs. And of course, so does Spain. A country which little more than 30 years ago was gripped in the clutches of a fascist dictatorship now supports one of the most progressive democracies in Europe.

DCRs are distinct from consumption services provided by programmes which prescribe and dispense opiates for dependent users. ${ }^{5}$ There are three such pilots in the UK. ${ }^{6}$ However, we have no consumption rooms. Why not? This is a good question which an editorial in The Independent addressed succinctly. ${ }^{7}$ Readers can guess at the answers. The government's stance persists despite a recommendation from the highly respected Joseph Rowntree Foundation that a number of pilot rooms be introduced. ${ }^{4}$

The coordinator of the DCR, Javi Rio Navarro, remembers the pre-Gugg era when the streets were dirtier and declining industrial heritage was all the city had to boast. He has clear memories of the overdose related deaths which were a feature of the '80s and '90s and modestly informs me that there have been no such fatalities since the sala opened.

Centrally situated in an area with high rates of drug use and dealing, the sala occupies two floors of a conspicuous early 20th century building on the edge of the Nirvión, which Javi describes as 'our first sky scraper'.

From inside the DCR, I look out of the window and ask 'How can anyone need to use drugs with views like this?' We smile, knowing the question is naïve and rhetorical. Javi shows me the staircases leading down to the river where drug-taking used to be rife. He points upstream to Bilbao La Vieja where deals are done many times a day. I see a side to life to which the majority of tourists are oblivious.

The sala's objectives are to reduce mortality and morbidity by minimising risk. Access to needle exchange and hygienic areas for drug consumption are provided, alongside education around safe injecting. It's run by a multidisciplinary team of social workers, educators, nurses, and psychologists. The service is open for 8 hours daily, every day of the year. Outreach work is also provided for hard-toreach groups. These include women, young people, ethnic minorities, and groin or neck injectors. (Obviously, unsafe injecting is not allowed in the DCR).

Javi shows me the three different areas: 'La Sala de Inyección' (Injection Room), 'La Sala de Inhalado' (Smoking Room), and La Sala de Relax (which speaks for itself!). Here clients talk to each other and staff about their current concerns, while enjoying free filter coffee and smoking tobacco. (Staff do not have the right to indulge in the latter activity!). Workshops on topics such as basic life support and overdose management are provided regularly. More involved projects have centred round exhibitions of the clients' art work and the production of a magazine 'La Calle de Todos' (Everybody's Street).

Seventy to a hundred regular users come through the salas each day. There will only be about one new contact. These have to register, provide a medical history and sign a contract. This ensures they understand the basic rules of the sala.

A major frustration felt by the workers is their inability to influence the purity of the drugs, or even know what people are injecting. What's the solution? We debate the pros and cons of decriminalisation and heroin prescription for entrenched users. I imagine my patients being cared for and empowered in a place like this. It's much easier to educate about risk reduction and safe injecting when you have the person and the goods in front of you.

I visited the sala before the official opening time of 11.30 at Javi's request. It would have been fascinating to see the sala in action. If I were a real investigative journalist I would have hung around the side door later and approached people as they left. But I had a family who wanted some time with me and, ultimately I know what I would have heard; 
stories of damaged lives, difficult childhoods, shattered dreams. But, here in Bilbao, I was heartened to learn about a really radical service which supports and protects drug users, offering the chance to improve futures and heal the wounds of the past.

\section{Meg Thomas}

\section{Acknowledgements}

Many thanks to the Médicos del Mundo team at the Sala de Consumo Supervisado, Bilbao for their hospitality and for allowing me some insight into the service.

\section{REFERENCES}

1. Nieto M. San Francisco: marginalidad en el centro: Los guetos en Espana. San Francisco: marginalisation in the town centre: ghettos in Spain. Madrid: Elpais.com, 2006

2. Gutiérrez Estíbaliz B. Una Sala de Consumo Supervisado en Bilbao: Evolución y resultados tras dos años de funcionamiento. A drug consumption room in Bilbao: Progress and results after 3 years in operation. Report for the Cadiz government. Cadiz: 2002

3. Hedrich D, European Monitoring Centre for Drugs and Drug Addiction. European report on drug consumption rooms. Luxembourg: Office for Official Publications of the
European Communities, 2004

4. Joseph Rowntree Foundation. The Report of the Independent Working Group on Drug Consumption Rooms. York: Joseph Rowntree Foundation, 2006

5. Sheldon T. More than a quick fix. BMJ 2008; 336: 68-69.

6. Laurance J. Heroin: The solution? 2006, The Independent. http://www.independent.co.uk/news/uk/crime/heroin-thesolution-480734.html (accessed 9 Oct 2008).

7. Anonymous. Editorial: an injection of reality. 2006, The Independent. http://www.independent.co.uk/opinion/ leading-articles/leading-article-an-injection-of-reality480718.html (accessed 9 Oct 2008).

DOI: 10.3399/bjgp08X342714

\section{Down the rabbit hole}

'Down, down, down. Would the fall never come to an end?' Just as Alice followed the white rabbit, so have all of us gone down the economic hole and we don't know where it will end. The freefall that started in the US and has affected everyone else comes from the economic interdependency of the world economy. That is not a bad thing. We all share the planet. But, not only has the unregulated greed of Wall Street indebted my grandchildren, but it has also threatened any serious talk about healthcare reform, yet again. Health reform has dropped from the major domestic concern of the public a year ago to ranking down there with agricultural policy as we head into the final weeks of the election. Losing one's retirement or house or paying for gas to drive to a job that may not be there trumps paying the doctor. The healthcare crisis, of course, will be back and be more imposing after the realities of the financial meltdown becomes clear.

Opportunities for moving health reform may come out of this costly underwriting of banks and investment firms. Even though the large majority of Americans favour an overhaul of the system, policy theorists say it hasn't happened because the middle class has not yet felt enough pain to risk change. Now, as unemployed bankers, white collar workers, executives, financial advisors all look at a life without health insurance and maybe even join laid off auto workers and undocumented immigrants at the free clinics, there is a higher likelihood of serious talk about a basic level of care for everyone.

Universal health care is an economic issue that Americans disguise as a 'values' issue. 'Choice' is second only to 'change' as the most used word in America. Choice is a value when the country is so flush that health plans, like brands of breakfast cereals, each offer something different. But, cereal is cereal to those who have no food. So when the ranks of those who have no choice because they have no insurance grow, including millions from the celebrated middle class, there may be greater hope for agreeing on the value of everyone being in this together. The tipping point toward a system of universal coverage in the US may just be coming into view.

Barack Obama's story is one of the most compelling and moving ones in America. But the homestretch of this exhausting political circus known as the US Presidential election continues to have him portrayed by his rivals as an 'elitist', rather than the mixed race son of a hardscrabble Midwestern family, raised by a single mother on the edge of poverty who became the educated, community grounded person that he is today. 'Elitist' means he speaks clearly and in full sentences, he talks about social justice, equality and has an interesting, accomplished wife and children. His opponent has a stirring story and, because he is 72 years old, a more complicated one.

John McCain endured things few of us can imagine as a POW and seemed determined to use his experience to be a different and less predictable public official. But in the past 6 months, he has become nothing but predictable, despite his protestations to the contrary. His willingness to choose to run with someone whose entire international experience comprises living in a state between Russia and Canada and visiting neither is portrayed as bold by his loyalists and as thumbing his nose at the rest of the world by everyone else.

Obama's plan for universal coverage depends heavily on employer-funded insurance, uses tax relief for small businesses and covers the uninsured through pools and expanding Medicaid. He wants to create savings through managing drug costs and squeezing insurance companies, the two most powerful health lobbies. McCain insists that market competition will sort everything out and that giving families tax breaks with which to buy insurance will drive prices down. He is less clear about the increasing numbers of uninsured, however. His plan doesn't mention them. And he proposes to deal with the issue of access to care by putting clinics in shopping malls.

The deadline for this piece comes shortly before the election. I don't know the outcome. A vote for progressive, thoughtful, politics that DOES bring the Change We Need may still be possible in this country. But we have been stupid before and may be again. Look who we have in the White House. When Alice was leaving the Mad Hatter's Tea Party and opened the gate into the Garden of the Red Queen, she said 'Now, I'll manage better this time.' Whatever lurks on the other side of the next election in the US may be better. We can certainly hope so. Another possibility is that we might all lose our heads.

\section{John Frey}

DOI: 10.3399/bjgp08X342723 